\title{
Complete Tubal Abortion: A Rare Form of Ectopic Pregnancy
}

\author{
Bogdan Chirculescu', Raluca Chirculescu' ${ }^{2}$ Mioara Ionescu' ${ }^{2}$, Gheorghe Peltecu ${ }^{3}$, Anca Panaitescu ${ }^{3}$ \\ 'Department of Obstetrics and Gynecology, Filantropia Clinical Hospital, Bucharest, Romania \\ 2Department of Pathology, "Institute of Mother and Child's Care" - Polizu Hospital, Bucharest, Romania \\ ${ }^{3}$ Department of Obstetrics and Gynecology, Filantropia Clinical Hospital, Carol Davila University of Medicine and Pharmacy, \\ Bucharest, Romania
}

Corresponding author:

Gheorghe C. Peltecu, MD, PhD, FACS

Professor of Obstetrics and Gynecology Carol Davila University of Medicine and Pharmacy, Filantropia Hospital 11-13,Blvd. Ion Mihalache

Bucharest, Romania

E-mail: gheorghe.peltecu@gmail.com

\section{Rezumat}

Avortul tubar complet: o formă rară de sarcină ectopică

Avortul tubar se caracterizează prin eliminarea unui produs de concepție implantat ectopic la nivelul trompei uterine, prin ostiumul abdominal, în cavitatea peritoneală. Poate fi complet sau incomplet putând provoca hemoragie severă. Recunoaşterea avortului tubar complet poate reprezenta o provocare, însa este esențială, deoarece permite abordarea unei atitudini conservatoare, ce asigură păstratrea funcționalității tubare şi a fertilității, în absența tratamentului citostatic. Este prezentat cazul unei paciente în vârstă de 30 de ani ce se internează pentru durere în etajul abdominal inferior. Valoarea serică a B-hCG-ului a fost de $659.2 \mathrm{mU} / \mathrm{mL}$, iar examenul ecografic transvaginal a evidențiat prezența unei colecții lichidiene în spațiul Douglas. S-a intervenit laparoscopic pentru suspiciune de sarcină ectopică cu hemoperitoneu. Coroborarea nivelurilor serice ale B-hCG-ului în dinamică cu aspectele laparoscopice au condus la stabilirea diagnosticului de avort tubar complet. Examenul histopatologic al țesutului recoltat laparoscopic a confirmat prezența de trofoblast intermediar. Examinarea ecografică facilitează diagnosticarea hemoperitoneului, dar nu oferă informații specifice pentru diagnosticul de avort tubar. Aspectul laparoscopic poate fi sugestiv pentru avortul tubar complet, însă diagnosticul se stabileşte coroborat cu dinamica B-hCG-ului. În aceste cazuri, atitudinea conservatoare poate fi suficientă, asigurând păstrarea funcției tubare şi a fertilității, fără a necesita terapie citostatică suplimentară.

Cuvinte cheie: avort tubar, sarcină ectopică, B-hCG, hemoperitoneu, conservarea fertilității

\section{Abstract}

Tubal abortion is characterized by the extrusion of an ectopic product of conception implanted in the fallopian tube through the abdominal ostium into the peritoneal cavity. It can be either complete or incomplete and may lead to 
severe bleeding. Recognition of a complete tubal abortion may be challenging but is essential because it allows conservative management which make possible preservation of tubal function and fertility without the need for further cytostatic therapy. A case of a 30 years-old woman admitted for lower abdominal pain is reported.The level of $\mathrm{B}$-hCG was $659.2 \mathrm{mU} / \mathrm{mL}$ and transvaginal ultrasound reveled a fluid collection in the pouch of Douglas. Laparoscopy was subsequently performed for the suspicion of ectopic pregnancy with hemoperitoneum. Corroborating the $\mathrm{B}$-hCG dynamics with the laparoscopic findings, the diagnosis of complete tubal abortion was established. The histopathological examination confirmed the presence of intermediate trophoblastic cells in the tissue collected during laparoscopy. Ultrasound examination helps recognition of hemoperitoneum but adds little value to the diagnosis of tubal abortion. Laparoscopic findings alone are only suggestive for complete tubal abortion but in combination with B-hCG dynamics, the diagnosis can be established. Conservative management might be sufficient in complete tubal abortion and ensures preservation of tubal function and fertility.

Key words: tubal abortion, ectopic pregnancy, B-hCG, hemoperitoneum, fertility

\section{Introduction}

Ectopic pregnancy represents $1-2 \%$ of all pregnancies and are the leading cause of gynecological emergencies $(1,2)$. The most common location for an ectopic pregnancy is in the fallopian tubes (95\%) (2). When a pregnancy sets within the fallopian tubes, it can evolve either by tubal rupture or tubal abortion (3) both conditions being accompanied by bleeding. Bleeding from an ectopic pregnancy is the leading cause of maternal death during the first trimester of pregnancy (2). Ectopic pregnancy is also an important cause of morbidity and a high percentage of the affected patients may become infertile (4). Complete tubal abortion is important to diagnose because it allows for conservative management during laparoscopy which ensures preservation of tubal function and fertility, without requiring further cytostatic therapy. We present a case of complete tubal abortion diagnosed by combining the laparoscopic findings, histological evidence and the B-hCG dynamics.

\section{Case report}

A 30 years-old Caucasian woman was admitted to the emergency room with amenorrhea of 9 weeks and 2 days and lower abdominal pain of maximum intensity in the right iliac fossa. Symptoms started 12 hours prior to her presentation. Medical history revealed no delivery, irregular menstrual cycles, a prior termination of pregnancy for social reasons and a positive pregnancy test. On admission, the patient has no fever and a mild pallor of the skin was noted. The blood pressure was 110/68 mmHg and the heart rate of $109 \mathrm{bpm}$. The abdomen was with positive bowel sounds and slight tenderness localized in the lower abdomen, mainly in the left iliac fossa, with no rebound tenderness. Speculum examination of the vagina revealed a normal cervix, with a minimal bloody discharge. The uterus was slightly increased in volume and the annexes were bilaterally palpable and slightly sensitive. The transvaginal ultrasound revealed: a uterus size of $7 / 5.8 / 4.5 \mathrm{~cm}$ with endometrial thickness of $1.5 \mathrm{~cm}$; right ovary measuring $5.3 / 3.8 \mathrm{~cm}$ with a hematic cyst image of $3.5 \mathrm{~cm}$; left ovary of $2.5 / 1.8 \mathrm{~cm}$ with a normal follicular structure; fluid in Douglas' pouch with a height of $4 \mathrm{~cm}$. The laboratory results were unremarkable excepted of the hemoglobin level $9.9 \mathrm{~g} / \mathrm{dL}$. Beta-HCG level on admission was $659.2 \mathrm{mU} / \mathrm{ml}$ and $844 \mathrm{mU} / \mathrm{ml}$ after 24 hours. Throughout her hospitalization, the patient was hemodynamically stable and her symptoms were stable.

Based on the symptoms of the patient, of B-hCG dynamic and the sonographic findings, ectopic pregnancy with hemoperitoneum was suspected and diagnostic laparoscopy was proposed. During surgery blood and clots (approximately $300 \mathrm{ml}$ ) were found in the peritoneal cavity in the vesicouterine space, the pouch of Douglas and the bilateral parietocolic gutters. A pseudotumor mass consisting of blood clots and tissue was found in the pouch of Douglas. The uterus and both ovaries had normal aspect. Left fallopian tube was normal but the right fallopian tube showed minimal active bleeding through the abdominal ostium (Fig. $1 \mathrm{~A}^{-}$ $C)$. Saline washing and careful hemostasis were performed by compression and electrocoagulation. The pseudotumor mass was extracted for histopathological examination. The estimated blood loss was $300 \mathrm{ml}$. Postoperatively, the outcome of the patient was favorable and the patient was discharged in the day 3. Beta-hCG level in the day of discharge was $121.8 \mathrm{mU} / \mathrm{ml}$ and dropped to 54 $\mathrm{mU} / \mathrm{ml} 5$ days later. Histopathological examination of the pseudotumor mass revealed blood clots with small tissue fragments of tubal-type epithelium, 

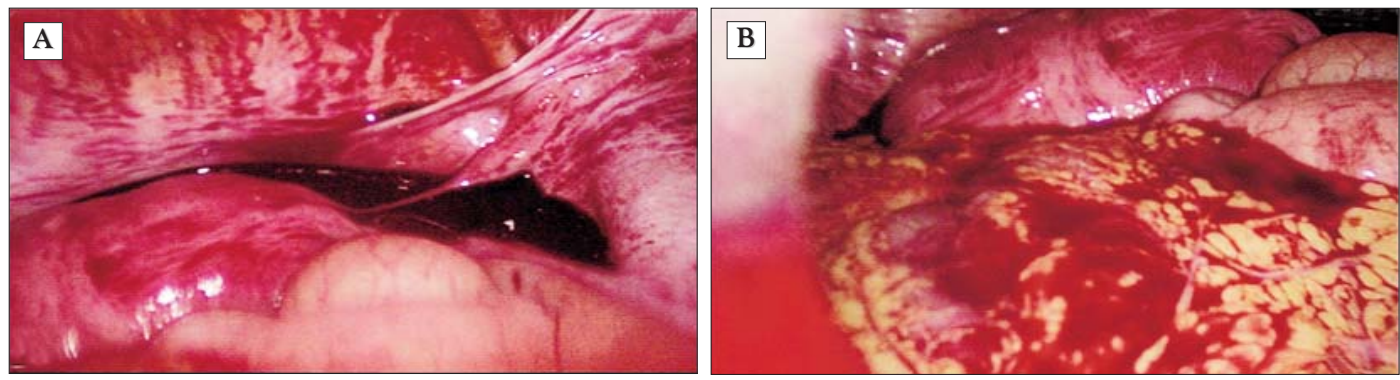

Figure 1. (A, B) Hemoperitoneum $(300 \mathrm{ml}$ of blood

(C) Blood clots in the pouch of Douglas.

Right fallopian tube with active bleeding through the abdominal ostium

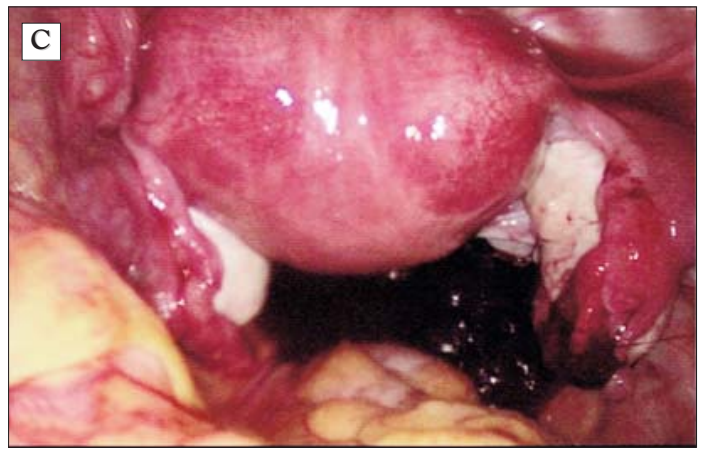

small fragments of intermediate trophoblast, rare syncytiotrophoblast cells and decidual aggregate. Immunohistochemical test for human placental lactogen (hPL) confirmed the trophoblastic nature of the cells (Fig. $2 \mathrm{~A}-\mathrm{H}$ ).

\section{Discussion}

Ectopic pregnancy is usually diagnosed within the first 2 months of pregnancy and symptoms include amenorrhea, abnormal vaginal bleeding and lower abdominal or pelvic pain (1). The vast majority of the ectopic pregnancies are tubal and the ampulla is the most commune site for implantation $(\sim 70 \%)$, the isthmus and infundibulum being less common $(3,5)$. Tubal pregnancy represents an inappropriate environment for implantation of the trophoblast (2), followed by penetration of arterial tubal vessels, hemorrhage and ovular detachment from the implantation site (3). The natural history of tubal ectopic pregnancy includes spontaneous expulsion from the abdominal ostium (tubal

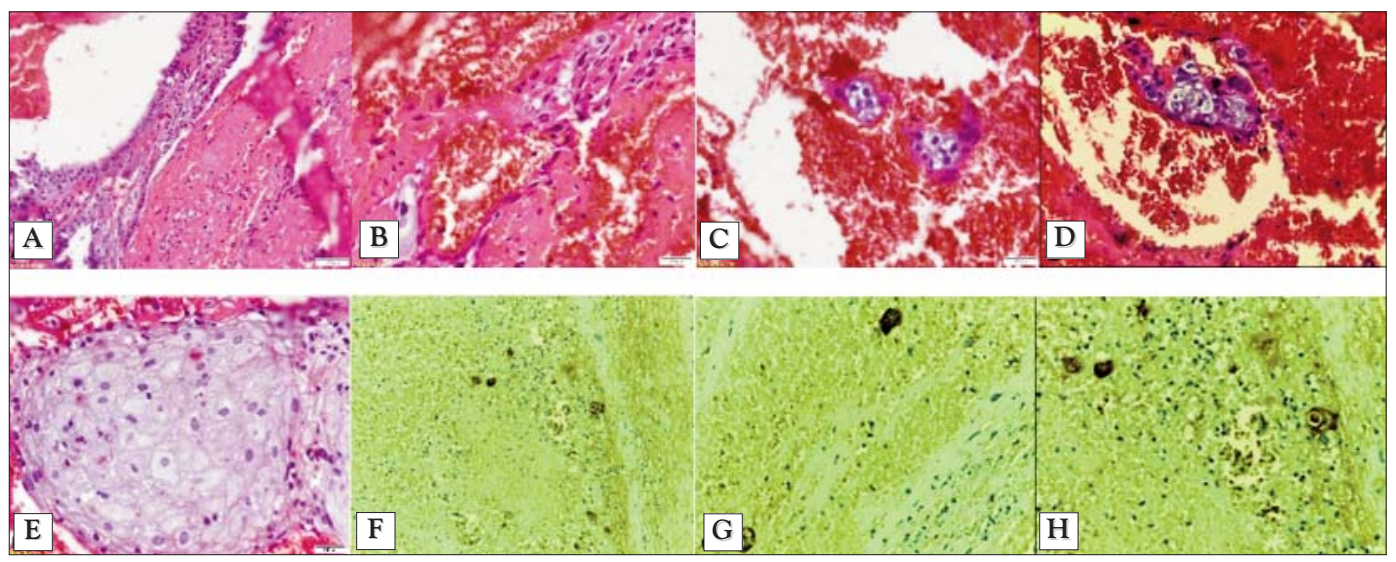

Figure 2. (A) Fragment of tubal-type epithelium (20X, H\&E). (B) Syncytiotrophoblast cells (40X, H\&E). (C, D) Fragments of intermediate trophoblast with rare syncytiotrophoblast cells (2OX, H\&E). (E) Clustterofdecidual cells (40X, H\&E). $(\mathrm{F}, \mathrm{G}, \mathrm{H})$ Immunostaining for $\mathrm{hPL}$ showing strong expression in the trophoblast cell population (10X, 20X, 40X). Legend. H\&E: Hematoxilin-eosine; X 10, 20, 40: magnification 
abortion) (1), embryo death and involution of the conceptus (3). In most of the cases, when early diagnosis is delayed the continued growth of the trophoblast with lead to rupture of the tubal wall and hemoperitoneum (2).

Tubal abortion represents the extrusion of the product of conception through the abdominal ostium of the fallopian tube in the peritoneal cavity. $(1,2,3,6)$. It can be complete, when the product of conception is entirely removed or incomplete when the product of conception remains attached to the implantation site or is only partially removed (3) Tubal abortion may be followed by resorption of the tissue $(2,3,6)$ or trophoblastic re-implantation in the abdominal cavity (abdominal or ovarian pregnancy) $(1,2,3,6,7)$.

No actual data are available on the incidence of the tubal abortion. Incidence rates have been reported to be $2.5 \%$ (3). In older series, the relative frequencies of tubal abortion varied from $6 \%$ to $73 \%$ of all tubal pregnancies (3). Differences in incidence rates may reflect the diagnostic difficulties and different pathologic definitions of tubal abortion.

The classical symptom associated with tubal pregnancy is lower abdominal pain (2) due to tubal distention. Further distention is associated with tubal contractions causing colicky pain. If the process continues, with expulsion of the gestational product into the peritoneal cavity, the pain becomes severe and acute signs of peritoneal irritation (3) are noted. In our case the patient was admitted with subtle clinical changes, which remained stable during preoperative hospitalization. Rival et al. have made similar observations in an analysis of 132 cases of ectopic pregnancies, were non-acute symptoms had been reported in most of the cases of tubal abortion (86\%) (3).

Tubal abortion is important to recognize because it meets the requirements for conservative treatment techniques. In the past, the treatment of choice for tubal gestations were total or partial salpingectomy or salpingo-oophorectomy. Over time, many techniques have been developed to convert an incomplete abortion to a complete one. The least invasive method was the digital expression or "milking", and the most aggressive method was suction or blunt curettage through the fimbriated ostium (3). Nowadays, because of the concern about fertility, conservative management is the mainstay of treatment (3). A non-surgical management, based on the potential of resorption and spontaneous regression of tubal abortion (2) has been proposed but this approach is not supported by studies. The presence of blood clots intraperitoneally, can cause tissue inflammation (2) with subsequent formation of adhesions, infertility and chronic pelvic pain (3). Laparoscopy offers the possibility to remove blood and the aborted tissue from the peritoneal cavity and to perform hemostasis. In our case, the normal gross appearance of the fallopian tube and the successful hemostasis at the fimbrial end allowed the preservation of the tube, and thus fertility. This approach was possible due to early detection which allowed conservative management.

Beta-hCG levels were followed up to ensure a gradual decline. In complete abortion the $\mathrm{B}$-hCG level should fall with a half-life of 24 hours (4). The level dropped from $844 \mathrm{mU} / \mathrm{ml}$ to $121,8 \mathrm{mU} / \mathrm{ml}$ in 3 days, and to $54 \mathrm{mU} / \mathrm{ml}$ in 5 days, confirming the diagnosis of complete tubal abortion.

\section{Conclusion}

Tubal abortion is a rare entity. Laparoscopic findings are suggestive for tubal abortion but the combination with B-hCG dynamics establishes the diagnosis of complete tubal abortion. Conservative management might be sufficient in complete tubal abortion and ensures preservation of tubal anatomy and fertility, without requiring further cytostatic therapy.

\section{References}

1. Peltecu G. Sarcina extrauterina. In: Tratat de Chirurgie - Obstetrica si Ginecologie, sub red. Popescu I, Ciuce C. Editia all-a. Bucuresti: Edit. Academiei Romane; 2014. p. 41-46.

2. Cunningham GF, Bradshaw KD, Halvorson LM, Schaffer JI, Schorge JO, Hoffman BL. Sarcina etrauterina. Williams Ginecologie, Second Edition. Mc Graw Hill; 2008. p. 198-215.

3. Casp E, Sherman D. Tubal abortion and infundibular ectopic pregnancy. Clin Obstet and Gynecol. 1987;30(1):155-63.

4. Elito JJ. Clinical treatment of unruptured ectopic pregnancy. Ectopic pregnancy - modern diagnosis and management. 2011. p. 177-201.

5. Paula J. Adams Hillard. The 5-Minute Obstetrics and Gynecology Consult. Lippincott Williams \& Wilkins. 2008. p. 380-381.

6. Tulandi T. Ectopic pregnancy: Clinical manifestations and diagnosis. (Internet). 2016 Oct. Available from: http://www.uptodate.com/ contents/ectopic-pregnancy-clinical-manifestations-and-diagnosis

7. Porwal S, Gupta R. Secondary abdominal pregnancy following tubal abortion: a unique case. J Pharm Biomed Sci. 2012;16 (06):1-2 